\title{
Desain Pengembangan Kurikulum Pendidikan Dasar
}

\author{
Masdiono \\ Kepala Madrasah MIN 4 Lombok Tengah \\ masdi@gmail.com
}

\begin{abstract}
Abstrak
Desain harus mendorong guru mempertimbangkan berbagai pengalaman belajar anak yang diperoleh diluar sekolah dan mengaitkannya dengan kegiatan belajar di sekolah.

Desain harus menyediakan pengalaman belajar yang berkesinambungan. Kurikulum harus di desain agar dapat membantu siswa mengembangkan watak, kepribadian, pengalaman, dan nilai-nilai demokrasi yang menjiwai kultur.Desain kurikulum harus realistis, layak, dan dapat diterima.

Tahapan Desain Pengembangan Kurikulum, Mengidentifikasikan misi institusi dan kebutuhan para pengguna pendidikan. Penilaian kebutuhan pembelajar. Menetapkan tujuan kurikulum. Pemilihan strategi pendidikan. Implementasi kurikulum yang baru. Evaluasi dan umpan balik untuk memperbaiki kurikulum.
\end{abstract}

Kata Kunci: Pengembangan Kurikulum Pendidikan Dasar 


\section{A. LATAR BELAKANG}

Pembinaan kurikulum adalah kegiatan yang mengacu pada usaha untuk melaksanakan, mempertahankan, dan menyempurnakan kurikulum yang telah ada, guna memperoleh hasil yang maksimal. Pelaksanaan kurikulum sendiri diwujudkan dalam proses belajar mengajar sesuai dengan prinsip-prinsip dan tuntutan kurikulum yang dikembangkan sebelumnya bagi pendidikan/sekolah tertentu. Dengan demikian, pembinaan kurikulum di sekolah dilakukan setelah melalui tahap pengembangan kurikulum, atau setelah terbentuknya kurikulum baru.

Pengembangan kurikulum sebagai tahap lanjutan dari pembinaan, yaitu kegiatan yang mengacu untuk menghasilkan suatu kurikulum baru. Dalam kegiatan tersebut meliputi penyusunan-penyusunan, pelaksanaan, penilaian, dan penyempurnaan. Melalui tahap-tahap tersebutlah akan menghasilkan kurikulum baru. Dan dengan terbentuknya kurikulum baru, maka tugas pengembangan telah selesai.

Pengembangan kurikulum adalah sebuah proses yang tidak pernah ada titik awal dan akhirnya. Karena pengembangan kurikulum ini merupakan suatu proses yang tertumpu pada unsur-unsur dalam kurikulum, yang didalamnya meliputi tujuan, metode, material, penilaian dan timbal balik (feed back).

Esensi dari pengembangan kurikulum adalah proses identifikasi, analisis, sintesis, evaluasi, pengambilan keputusan dan kreasi elemen-elemen kurikulum. Sementara dukungan masyarakat terhadap sekolah dalam rangka menerapkan kurikulum juga menjadi sangat pasif.

Kepasifan ini mungkin terjadi karena sosialisasi mengenai kurikulum kepada masyarakat sangat kurang, bahkan membingungkan. Pada akhirnya semua persoalan ini diserahkan kepada sekolah dan akibatnya keterlibatan masyarakat atau orang tua menjadi sangat kurang. Dalam pengertian lain, masyarakat yang tertutup dan apriori terhadap munculnya berbagai inovasi akan mengahambat implementasi kurikulum.

\section{B. PEMBAHASAN}

\section{Pengertian Desain Pengengembangan Kurikulum}

Beberapa pengertian desain kurikulum menurut para ahli, di antaranya adalah: 
a. Menurut Oemar Hamalik, pengertian desain adalah suatu petunjuk yang memberi dasar, arah, tujuan dan teknik yang ditempuh dalam memulai dan melaksanakan kegiatan.

b. Menurut Nana S. Sukmadinata, desain kurikulum adalah menyangkut pola pengorganisasian unsur-unsur atau komponen kurikulum. Penyusunan desain kurikulum dapat dilihat dari dua dimensi, yaitu dimensi horizontal dan vertikal. Dimensi horizontal berkenaan dengan penyusunan dari lingkup isi kurikulum. Sedangkan dimensi vertikal menyangkut penyusunan sekuens bahan berdasarkan urutan tingkat kesukaran. ${ }^{1}$

c. Menurut Longstreet. Desain kurikulum ini merupakan desain kurikulum yang berpusat pada pengetahuan (the knowledge centered design) yang dirancang berdasarkan struktur disiplin ilmu, oleh karena itu model desain ini dinamakan juga model kurikulum subjek akademis yang penekanannya diarahkan untuk pengembangan itelektual siswa.

\section{Prinsip-Prinsip Dalam Mendesain}

Saylor mengajukan delapan prinsip ketika akan mendesain kurikulum, prinsip-prinsip tersebut adalah sebagai berikut:

a. Desain kurikulum harus memudahkan dan mendorong seleksi serta pengembangan semua jenis pengalaman belajar yang esensial bagi pencapaian prestasi belajar, sesuai dengan hasil yang diharapkan.

b. Desain memuat berbagai pengalaman belajar yang bermakna dalam rangka merealisasikan tujuan-tujuan pendidikan, khususnya bagi kelompok siswa yang belajar dengan bimbingan guru;

c. Desain harus memungkinkan dan menyediakan peluang bagi guru untuk menggunakan prinsip-prinsip belajar dalam memilih, membimbing, dan mengembangkan berbagai kegiatan belajar di sekolah;

d. Desain harus memungkinkan guru untuk menyesuaikan pengalaman dengan kebutuhan, kapasitas, dan tingkat kematangan siswa.

e. Desain harus mendorong guru mempertimbangkan berbagai pengalaman belajar anak yang diperoleh diluar sekolah dan mengaitkannya dengan kegiatan belajar di sekolah.

${ }^{1}$ Sukmadinata, Nana Sy. Pengembangan Kurikulum: Teori dan Parktek. Bandung : PT Remaja Rosdakarya 2001. Hal. 13 
f. Kurikulum harus di desain agar dapat membantu siswa mengembangkan watak, kepribadian, pengalaman, dan nilai-nilai demokrasi yang menjiwai kultur.

\section{Jenis Desain Kurikulum}

\section{Menurut Longstrreet \& Shane ada 4 macam desain Kurikulum: ${ }^{2}$}

Longstreet mendefinisikan desain kurikulum merupakan desain kurikulum yang berpusat kepada pengetahuan (the knowledge centered desain) yang dirancang berdasarkan struktur disiplin ilmu, oleh karena itu model desain ini juga dinamakan model kurikulum subjek akademis yang penekanannya diarahkan untuk pengembangan intelektual siswa.

Ada tiga bentuk organisisi kurikulum yang berorientasi pada disiplin ilmu, yaitu: subject centered desain, learned centered desain, problem centered desain. Setiap desain kurikukum memberikan teknik atau cara yang efektif dalam proses pembelajaran agar berjalan dengan efektif dan efisien. Tetapi tidak setiap desain kurikulum dapat dijadikan pedoman dalam melaksanakn proses pembelajaran, karena setiap desain kurikulum memiliki kelebihan dan kekurangan dalam pelaksanannya.

\section{1) Subject Centered Design}

Subject centered design curiculum merupakan bentuk desain yang paling populer, paling tua dan paling banyak digunakan. Dalam subject centered design, kurikulum dipusatkan pada isi atau materi yang akan diajarkan. Kurikulum tersusun atas sejumlah mata-mata pelajaran, dan matamata pelajaran tersebut diajarkan secara terpisah-pisah. Karena terpisahpisahnya itu maka kurikulum ini disebut juga separated subject curiculum.

Subject centered design berkembang dari konsep pendidikan klasik yang menenkankan pengetahuan, nilai-nilai dan warisan budaya masa lalu, dan berupaya untuk mewariskannya kepada generasi berikutnya. Karena mengutamakan isi atau bahan ajar atau subject matter tersebut, maka desain kurikulum ini disebut juga subject academic curriculum.

\section{2) The Subject Design}

\section{${ }^{2}$ Ibid.}


The Subject Curiculum merupakan bentuk desain yang paling murni dari subject centered design. Materi pelajaran disajikan secara terpisahpisah dalam bentuk mata-mata pelajaran. Model desain ini telah ada sejak lama. Orang-orang Yunani kemudian Romaaw imengembangkan Trivium dan Quadrivium. Trivium meliputi gramatika, logika, dan retorika, sedangkan Quadrivium meliputi matematiks, geometri, astonomi, dan musik. Paada saat itu pendidikan tidak diarahkan pada mencari nafkah, tapi oada pembentuakan pribadi dan status sosial (Liberal Art). Pendidikan hanya di peruntukan bagi anak-anak golongan bangsawan yang tidak usah bekerja mencari nafkah. ${ }^{3}$

Adapun kelemahan-kelemahan bentuk kurikulum ini adalah:

(1) Kurikulum memberikan pengetahuan terpisah-pisah, satu terlepas dari yang lainnya.

(2) Isi kurikulum diambil dari masa lalu, terlepas dari kejadian-kejadian yang hangat, yang sedang berlangsung saat sekarang. Kurikulum ini kurang memperhatiakan minat, kebuutuhan dan pengalaman peserta didik

(3) Isi kurikulum disusun berdasarkan sistematika ilmu sering menimbulkan kesukaran di dalam mempelajari dan menggunakannya

(4) Kurikulum lebih mengutamakan isi dan kurang memperhatiakn cara penyampaian. Cara penyampaian utama adalah ekspositori yang menyebabkan peran siswa pasif.

Meskipun ada kelemahan-kelemahan di atas, bentuk desain kurikulum ini mempunyai beberapa kelebihan karena kelebihan-kelebihan tersebut bentuk kurikulum ini lebih banyak dipakai, yaitu:

(a) Karena materi pelajaran diambil dari ilmu yang sudah tersusun secara sitematis logis, maka penyusunnya cukup mudah.

(b) Bentuk ini sudah di kenal sejak lama, baik oleh guru-guru maupun orang tua, sehingga lebih mudah untuk dilaksanakan.

(c) Bentuk ini memudahkan peserta didik untuk mengikuti pendidikan di perguruan tinggi, sebab pada perguruan tinggi umumnya menggunakan bentuk ini.

${ }^{3}$ Lias Hasibuan. Kurikulum dan Pemikiran Pendidikan. Jakarta: Gaung Persada Press, 2010. hal.44 
(d) Bentuk ini dapat dilaksanakan secara efisien, karena metode utamanya adalah metode ekspositori yang dikenal tingkat efisiennya cukup tinggi

(e) Bentuk ini sagat ampuh sebagai alat untuk melestarikan dan mewariskan warisan budaya masa lalu.

Dengan adanya kelemahan-kelemahan di atas pengembang kurikulum subject design tidak tinggal diam, mereka berusaha untuk memperbaikinya. Dalam rumpun subject centered, the broad field designmerupakan pengembangan dari bentuk ini. Begitu juga pengembangan bentuk-bentuk lain di luar subject centered, the broad field design, areas of living design dan core design.

\section{Tahap-Tahap Desain Kurikulum}

Perancangan kurikulum dapat digolongkan dalam 6 langkah yaitu

1) Mengidentifikasikan misi institusi dan kebutuhan para pengguna pendidikan.

Langkah pertama yang paling penting adalah untuk memahami misi dari institusi dimana kurikulum itu dibuat. Misalnya misi dari fakultas pendidikan adalah untuk melatih para calon pendidik agar dapat memberikan pelayanan pendidikan kepada masyarakat. Sebagai konsekuensinya, pengembang kurikulum harus mengetahui dan mengerti kebutuhan dari para pengguna kurikulum tersebut (siswa, pengajar, administrator pendidikan, badan profesional, pemerintah, dsb) yang dapat menentukan tipe profil lulusan yang diinginkan oleh fakultas, antara lain: (1) menguasai dasar-dasar metode pengajaran; (2) mempunyai kompetensi pendidikan yang tinggi; (3) memiliki kemampuan analisis yang kritis; (4) mampu mengembangkan kemampuan diri; (5) memiliki keahlian berkomunikasi yang baik; (5) memiliki rasa empati dan etika yang baik. ${ }^{4}$

2) Penilaian kebutuhan pembelajar. Langkah ini sering terabaikan oleh pengembang kurikulum. Begitu ada siswa yang potensial, pengembang kurikulum harus bisa mengetahui sampai dimana titik kemampuan maupun kelemahan siswa-siswanya tersebut. Untuk itulah diperlukan data karakteristik siswa secara perorangan. Karakteristik siswa yang perlu

${ }^{4}$ Muhaimin. Pengembangan Kurikulum Pendidikan Agama Islam. (Jakarta: Rajagrafindo Persada, 2010. hal. 76 
diketahui mencakup kompetensi awal pembelajar, kemampuan untuk memenuhi standar yang telah ditentukan oleh institusi, tujuan dan prioritas individu, latar belakang personal dan alasan pembelajar memasuki institusi, sikap mengenai disiplin, dan asumsi awal pembelajar mengenai program studi.

3) Menetapkan tujuan kurikulum. Langkah ini sangat penting karena menentukan filosofi instruksional dan menentukan metode pembelajaran yang paling efektif. Selain itu tujuan pembelajaran juga dapat digunakan untuk menentukan desain dan pemilihan prosedur dan instrument penilaian. Karena tujuan yang jelas dan tersusun dengan baik sangat penting untuk menentukan fokus dari kurikulum yang akan dibuat, pembuat kurikulum harus dilatih dengan baik untuk membuat tujuan instruksional.

\section{4) Pemilihan strategi pendidikan.}

Pemilihan strategi pendidikan harus didasarkan pada tiga prinsip utama. Yang pertama, metode pendidikan harus sejalan dengan tujuan pendidikan. Kedua, penggunaan beragam metode pendidikan lebih baik, daripada hanya satu metode saja, karena kurikulum harus menjawab tantangan akan keragaman tipe belajar siswa dan tujuan pendidikan yang berbeda-beda. Yang terakhir, pengembang kurikulum harus memastikan bahwa kurikulum tersebut sesuai dengan materi pelajaran dan kompetensi pengajar.

\section{5) Implementasi kurikulum yang baru.}

Mendesain sebuah kurikulum adalah hal yang amat menarik dan dan penuh daya kreatif dalam pengembangan kurikulum. Akan tetapi tujuan utamanya bukan untuk mendesain kurikulum yang paling ideal dan paling baik, akan tetapi bagaimana keberhasilan penerapannya dalam praktek pendidikan. Kondisi dan syarat keberhasilan penerapan kurikulum meliputi keikutsertaan administrator pendidikan dalam proses implementasi kurikulum dan alokasi sumber daya yang cukup. Sebelum menerapkan sebuah kurikulum yang baru, pengembang kurikulum harus mendapatkan dukungan yang kuat dari pimpinan institusi yang berwenang. Setelah tahap pertama dari implementasi kurikulum yang baru tersebut dilakukan, harus dilakukan penilaian formal untuk mengontrol proses implementasi kurikulum dan untuk 
menetapkan hubungan antara tujuan institusional, pembelajaran, dan kurikulum.

6) Evaluasi dan umpan balik untuk memperbaiki kurikulum.

Meskipun evaluasi merupakan langkah akhir dari pelaksanaan kurikulum, akan tetapi bukan berarti ini merupakan tindakan akhir. Data hasil evaluasi yang telah dikumpulkan harus digunakan sebagai criteria untuk menyesuaikan kurikulum tersebut dengan tujuan program studi atau misi dari institusi.

Kurikulum harus dievaluasi, dan diperbaiki, dan dilakukan inofasi-inofasi yang bervariatif karena kurikulum bukanlah suatu sistem yang statis. Umpan balik dari pengajar dan siswa perlu dipertimbangkan secara terus menerus untuk meningkatkan hasil belajar siswa. Kesimpulannya, kurikulum merupakan suatu rencana akademik yang merupakan rancangan pelaksanaan dimana: (a) tujuan dan hasil dari kurikulum dijabarkan secara jelas, (b) proses untuk mencapai tujuan tersebut teridentifikasi dengan baik, (c) kurikulum merupakan alat untuk menilai keberhasilan pendidikan, (d) ulasan sistematik dan perbaikan termasuk di dalamnya. ${ }^{5}$

${ }^{5}$ Ibid. 


\section{KESIMPULAN}

Pengertian desain kurikulum adalah rancangan, pola, atau model. Sedangkan desain kurikulum merupakan suatu pengorganisasian tujuan, isi, serta proses belajar yang akan diikuti siswa pada berbagai tahap perkembangan pendidikan. Mendesain kurikulum berarti menyusun rancangan atau model kurikulum sesuai dengan misi dan visi sekolah.

Dalam desain kurikulum akan tergambar unsur-unsur dari kurikulum, hubungan antara satu unsur dengan unsur lainnya, prinsip prinsip pengorganisasian, serta halhal yang diperlukan dalam pelaksanaannya.Tugas dan peran seorang desainer kurikulum adalah menentukan bahan dan cara mengembangkan kurikulum yang baru sesuai dengan kondisi lingkungan pendidikan.

Desain kurikulum harus memudahkan dan mendorong semua jenis pengalaman belajar bagi pencapaian prestasi belajar siswa, Desain memuat berbagai pengalaman belajar yang bermakna dalam rangka merealisasikan tujuan-tujuan pendidikan, Desain harus memungkinkan dan menyediakan peluang bagi guru untuk menggunakan prinsip-prinsip belajar dalam kegiatan belajar di sekolah, Desain harus memungkinkan guru untuk menyesuaikan pengalaman dengan kebutuhan, kapasitas, dan tingkat kematangan siswa. 


\section{DAFTAR PUSTAKA}

Beauchamp, Curriculum Theory, dalam, Wina Sanjaya. Kurikulum dan Pembelajaran, Teori dan Praktek Pengembangan Kurikulum Tingkat Satuan Pendidikan (KTSP), Jakarata: Kencana Media Group, 2010.

Lias Hasibuan. Kurikulum dan Pemikiran Pendidikan. Jakarta: Gaung Persada Press, 2010.

Muhaimin. Pengembangan Kurikulum Pendidikan Agama Islam. (Jakarta: Rajagrafindo Persada, 2010).

Soetopo \& Soemanto. Pembinaandan Pengembangan Kurikulum: Sebagai Substansi Problem Administrasi Pendidikan. Jakarta; Bumi Aksara. 1993

Sukmadinata, Nana Sy. Pengembangan Kurikulum: Teori dan Parktek. Bandung : PT Remaja Rosdakarya 2001. 